\title{
Vidéki egyetemek harmadik missziós tevékenysége: a társadalmi tudásmegosztás hatásai
}

\author{
A magyar szakirodalom áttekintése
}

Az elmúlt két évtized felsôoktatási trendjei nyomán oly mértékben felerốsödött a verseny a nemzeti, illetve nemzetközi felsóoktatási piacon, hogy az egyes intézményeknek minden lehetséges módon törekedniük kell reputációjuk növelésére, brandjük erôsitésére, képzési palettájuknak az aktuális országos-regionális-

helyi munkaerópiac igényeihez való igazitására, valamint gazdasági és társadalmi kapcsolataik továbbfejlesztésére, hogy bevonzhassák, megtarthassák s fejleszthessék a kivánt számú és minóségú hallgatói bázist (Hrubos, 2013). Ezáltal nemcsak normatív bevételeik növekedhetnek, hanem tehetséges hallgatóik kreativitása és innovatív ötletei, valamint az üzleti és társadalmi partnerekkel való hatékony együttmúködés nyomán fokozhatják $K+F+I$ tevékenységeiket, s növelhetik tudományos és társadalmi reputációjukat, illetve saját bevételeiket. E célok elérésének egyik eszköze lehet a felsóoktatási intézmények harmadik küldetésének,

az oktatás és kutatás mellé felvállalt közszolgálati-fejlesztó

feladatkörnek (Gál, 2016) a kiteljesitése és kiaknázása, mely mára, bár különbözó mélységben, a magyarországi felsóoktatási intézményi stratégiák részévé vált (Bander, 2011).

\section{Bevezetés}

A harmadik missziós tevékenységek köre rendkívül sokszínü, hátterét az egyetemek tudásbázisa és infrastrukturális lehetőségei, pályázati és saját forrásai, valamint helyi önkormányzati-ipari-gazdasági-társadalmi kapcsolatai biztosítják, amit immáron az ún. Quadruple Helix, azaz a négyes spirál modell ír le (Halász, 2018; Hrubos, 2013). A humboldti kutatóegyetem fokozatos átalakulása a gazdálkodó-szolgáltató-kiterjesztett egyetem fejlődési vonala mentén mára a vállalkozói egyetem eszményképében teljesedett ki (HEInnovate, 2018; Hrubos, 2004), melyet mind az OECD 2015-ben elfogadott innovációs stratégiája, mind az Európai Unió 2017-ben frissített felsőoktatási stratégiája követendő példaként állít Európa felsőoktatási intézményei elé (Halász, 2018). Ez pedig a legteljesebb értelemben olvasztja magába a harmadik misszió fogalmát, amint azt Gibb megfogalmazza: 
„a vállalkozói felsőoktatási intézmények úgy kerülnek kialakításra, hogy felhatalmazhassák dolgozóikat és hallgatóikat a vállalkozó szellem, az innováció és a kreativitás kibontakoztatására a kutatásban, a tanításban, valamint a tudás keresésében és hasznosításában, átlépve a (meglévő) határokat. A nagyfokú bizonytalansággal és összetettséggel jellemezhető társadalmi környezetben hatékonyan képesek hozzájárulni a tanulás fokozásához, és elkötelezettek a közösségi érték elöállítása mellett a nyílt elköteleződés, valamint a kölcsönös tanulás, felfedezés és csere folyamatain keresztül a társadalom minden érdekhordozója bevonásával, legyen az helyi, nemzeti vagy nemzetközi." (Gibb, 2013, idézi HeInnovate, 2018).

Kutatási témám a magyarországi vidéki egyetemek azon harmadik missziós tevékenysége, amely az egyetem közösségi elköteleződése jegyében a helyi-regionális gazdasági és társadalmi partnerek és érdekhordozók felé irányuló tudástranszfer- és tudásdiffúziós aktivitásokban nyilvánul meg. Ezek céljait, megvalósításuk módját, eredményeit és nehézségeit, valamint az érdekhordozókra kiváltott hatásait kívánom megvizsgálni, különös tekintettel az intézmények számára oly fontos hallgatóilétszám-növelés tekintetében. Ezért tanulmányomban az alábbi kapcsolódó fogalmakat, illetve jelenségeket szeretném röviden bemutatni az általam eddig megismert magyar és részben angol nyelvü szakirodalom alapján:

1. A felsőoktatási intézmények harmadik missziója: stratégiai fontosságúvá válásának okai és fogalma

2. A Quadruple és Quintuple Helix modellek

3. Egyetemfejlődés: a vállalkozói és az elkötelezett egyetem

4. Egyetemi társadalmi felelősségvállalás

5. Harmadik misszió és társadalmi felelősségvállalás: néhány magyarországi egyetem példája

6. A harmadik misszió és a társadalmi innováció mérési lehetőségei: hazai kutatások

\section{A felsőoktatási intézmények harmadik missziója}

Mi miatt került a harmadik misszió az intézményi stratégiák prioritásai közé? Felértékelödése szempontjából az elmúlt két évtized nemzetközi trendjei közül különösen relevánsak az alábbiak: egyrészt a mennyiségi expanzió, valamint tömegesedés, ami jelenleg Ázsiában és a BRIC országokban közelít tetőpontjához (Hrubos, 2014), illetve például az Európai Unió EU2020 programjának stratégiai célkitűzései kapcsán érvényesül; másrészt az innovációra és a diplomás foglalkoztathatóságra való fókuszálás (Halász, 2018), melyet a civil kutatás megjelenése és a nemzeti képességpolitikák megszületése jelez (pl. Nagy-Britannia national skills policyja) (Halász, 2018; Hrubos, 2018). Továbbá az intézményi, szak- és hallgatói diverzifikálódás, a nem-hagyományos hallgatói csoportok növekvő aránya többek között a megállíthatatlannak tünő európai demográfiai hanyatlás és elöregedő társadalmak következtében, a tudásgazdaság és tudás alapú társadalom számára alapvető élethoszszig-tartó tanulás irányelveinek dominanciája, s a mindezeket támogató társadalmi inklúzió koncepciója (Kálmán, 2013). Mindezeken túl meg kell még említeni az állami támogatások csökkenését és az egyetemek finanszírozási autonómiájával együtt járó gazdasági felelősség kényszereit, a nemzetközi felsőoktatási verseny magas minőségkövetelményeit, valamint a harmadik missziót is figyelembe vevő európai U-Map és U-Multirank rangsor-rendszereit (Barakonyi, 2009; Halász, 2013; Hrubos, 2014).

Ebben a 21. századi turbulens müködési környezetben a felsőoktatási intézményeknek újra kell definiálni és pozícionálni magukat, megerősítve regionális, nemzeti és 
nemzetközi versenyhelyzetüket, melyben a harmadik misszió egyrészt megkülönböztető tényezőként segíthet, másrészt demonstrálja az intézmények közvetlen elköteleződését a helyi-regionális társadalom szolgálata iránt (Bander, 2011; Carrión, Garcia-Gutiérrez, Bas és Carot, 2012; Hrubos, 2013; Kálmán, 2013). Ugyanis az egyes országok társadalma és politikai döntéshozói fokozott mértékben elvárják, hogy az egyetemek tudásteremtő és tudásközvetítő képességeik nyomán hozzájáruljanak a különféle társadalmi problémák megoldásához, az innováció motorjaként növeljék az ország versenyképességét, valamint a kompetenciafejlesztésre és gyakorlati képzésre fókuszáló, magas minőségű oktatási tevékenységeik révén növeljék hallgatóik foglalkoztathatóságát (Kálmán, 2013; OECD/EU, 2017).

Ez az összetett felelősségvállalás, az ebből fakadó elköteleződés és aktív szerepvállalás, amit az egyetemek régiójuk, illetve helyi-regionális közösségeik gazdasági versenyképessége, társadalmi fejlődése, valamint fenntartható környezet- és életminősége érdekében fel kell vállaljanak az oktatás és kutatás első két missziója mellett, legközvetlenebb formában a közszolgálati-fejlesztő funkciót (Gál, 2016) jelölő harmadik misszió keretében valósul meg.

A harmadik misszió tehát legszélesebb értelemben mindazon oktatási, kutatási-innovációs és szolgáltatási tevékenység, amit a felsőoktatási intézmények társadalmi környezetük jólétének növelése érdekében végeznek (Bander, 2011). Részben továbbra is az első két funkcióból ágazik le (Hrubos, 2013), részben viszont a stratégiai fontosságúvá vált társadalmi elkötelezettségben nyilvánul meg egy rendkívül sokszínü és változékony szolgáltatási palettán keresztül, amit az intézmények helyi, regionális, de akár országos és mára nemzetközi érdekhordozóik 360 fokos köre számára nyújtanak. A társadalmi szerepvállalás a felsőoktatási intézmény egészét áthatja, spektrumában helyet kaphat „a for-profit szemlélettől az önkéntes munkáig a motivációk széles skálája”, s partneri együttmüködései kiterjednek más felsőoktatási intézményekre is (Hrubos, 2013. 36.).

Az egyetemek harmadik missziós tevékenységeinek közvetlen céljai tehát rendkívül változatosak és intézményenként eltérőek lehetnek: például a kívánt mennyiségű és minőségü hallgatói bázis bevonzása és fejlesztése; az innovációs kapacitás növelése;
Ebben a 21. századi turbulens múködési környezetben a felsốoktatási intézményeknek újra kell definiálni és pozícionálni magukat, megerósítve regionális, nemzeti és nemzetközi versenyhelyzetüket, melyben a harmadik misszió egyrészt megkülönböztetó tényezóként segithet, másrészt demonstrálja az intézmények közvetlen elkötelezódését a helyi-regionális társadalom szolgálata iránt

(Bander, 2011; Carrión, Garcia-Gutiérrez, Bas és Carot, 2012; Hrubos, 2013; Kálmán, 2013). Ugyanis az egyes országok társadalma és politikai döntéshozói fokozott mértékben elvárják, hogy az egyetemek tudásteremtố és tudásközvetitó képességeik nyomán hozzájáruljanak a különféle társadalmi problémák megoldásához, az innováció motorjaként növeljék az ország versenyképességét, valamint a kompetenciafejlesz-

tésre és gyakorlati képzésre fókuszáló, magas minôségú oktatási tevékenységeik révén növeljék hallgatóik foglalkoztat-

hatóságát (Kálmán, 2013; OECD/EU, 2017). 
a $\mathrm{K}+\mathrm{F}+\mathrm{I}$ tevékenységek körének bővítése és súlyának fokozása; az intézmény finanszírozási forrásainak kibővítése; az infrastukturális háttér fejlesztése; érdekhordozói kapcsolati hálójuk továbbfejlesztése; társadalmi felelősségvállalásuk növelése a szociális inklúzió jegyében, stb. Megvalósításuk pedig nem is történhetne az egyetem és a kormányzat, valamint a helyi-regionális gazdasági és társadalmi szereplök kölcsönös egymásrautaltsága és hatékony együttmüködése nélkül, melyet a már említett négyes spirál modellje, az ún. Quadruple Helix Model foglal keretbe.

\section{A Quadruple Helix és a Quintuple Helix modellek}

Leydesdorff és Etzkowitz Triple Helix, majd Quadruple és Quintuple Helix, azaz hármas, négyes, majd ötös spirál modelljei (Carayannis és Campbell, 2012; Carayannis, Grigoroudis, Campbell, Meissner és Stamati, 2018; Leydesdorff, 2013) a tudásalapú gazdaság és társadalom kialakulásának, müködésének és fejlődésének, illetve a fenntartható fejlődés biztosításának kereteit írják le a szereplők egyre bővülö köreivel és egymás közti komplex kölcsönhatásaikkal. A hármas spirál modellben a vállalkozó egyetem, a kormányzat és az ipari szféra kölcsönös együttmüködése a tudásteremtés, a tudás- és technológiatranszfer, valamint -alkalmazás, azaz innovációk születése érdekében valósul meg. Interakcióik terepei az olyan új szervezeti formák, mint az egyetemi spin-off cégek, az inkubátorházak vagy a start-up vállalkozások. A modell hangsúlyozza az egyetemek megnövekedett szerepét az innováció folyamatában, a szereplők, saját funkcióik betöltése mellett, egymás feladatköreinek részleges átvételét, illetve kiegészítését, ami az idő múlásával eltérő mértékü és formájú lehet, továbbá kölcsönös egymásra utaltságukat és a folyamatos kommunikáció szükségességét. Bár nem földrajzilag meghatározott kapcsolatrendszert ír le, a hármas spirál modell alapul szolgálhat hatékony regionális gazdaságpolitikák és innovációs rendszerek kialakításához (Leydesdorff, 2013; Polónyi, 2010; Vas, 2012).

A Quadruple Helix modellben a tudástermelés folyamatába negyedik szereplőként belép a társadalom is, azaz „a médiaalapú és kultúraalapú közösségi tér” és a „civil társadalom közege" (Carayannis és Campbell, 2012; Vas, 2012. 203.). Mivel a tudásalapú társadalomban a közösség szintén felhasználja és alkalmazza a tudást, ezért azt is be kell vonni a tudástermelés folyamatába, illetve a nemzeti-regionális-helyi innovációs rendszerek fejlesztésébe. Ezáltal olyan területek kerülnek be az új tudás létrehozásának folyamatába, mint pl. a kultúra, az értékek és életmód, a kreativitás, a média, a multikulturalizmus és a müvészet, melyek fokozzák az innovációs kapacitást. Végül pedig a Quintuple Helix modell egy ötödik kört von az eddigi szereplök köré, a tudásalapú társadalom és gazdaság természeti környezetét, azaz a fenntartható fejlődésre való fókuszálás szükségességét, mely az ún. zöld technológiák és innovációk fejlődéséhez vezet (Carayannis és Campbell, 2012; Gál, 2016; Reisinger és Dános, 2015; Vas, 2012).

A négyes spirál modell tehát a felsőoktatási intézményeket egy összetett innovációs ökoszisztéma részeként írja le, amiben a négy szereplö közös innovatív tevékenysége a helyi, regionális és országos gazdaság és társadalom fejlődését segíti elő. Annál is inkább, mert, amint azt az OECD Innovációs Stratégiája 2017-ben megfogalmazta, a tudásalapú társadalomban az állampolgárok, a gazdálkodó szervezetek és a társadalmi intézmények mind az innováció lehetéges forrásai, melyekkel a felsőoktatási intézményeknek együtt kell müködniük. Ezért tevékenységeiket ki kell terjeszteniük a társadalom minden egyes szegmensére (Halász, 2018; OECD/EU, 2017). Ezzel pedig a Quadruple Helix Model elvezet az egyetemi társadalmi felelősségvállalás és az elkötelezett egyetem fogalmához. 


\section{Egyetemfejlődés: a vállalkozói és elkötelezett egyetem}

Az elmúlt két évtized megannyi politikai, gazdasági, társadalmi, technikai és technológiai változása olyan kihívások elé állította és állítja Európa felsőoktatását, amelyek alapjaiban rendezték-rendezik át mind a brit, mind a francia, mind a német, humboldti egyetemi modellt. A változásokhoz való alkalmazkodás egyike a 21 . századi egyetem szerepeinek bővülése, a gazdálkodó-szolgáltatókiterjesztett egyetem fejlődési vonala mentén a fent meghatározott vállakozói egyetem eszményképére (HEInnovate, 2018; Hrubos, 2004; Reisinger és Dános, 2015). Ennek dimenzióit Burton Clark állapította meg a kilencvenes évek végén megjelent, s azóta klasszikussá vált könyvében (Hrubos, 2004), miszerint a vállalkozói vagy innovatív egyetem fö jellemzői, hogy erős és profeszszionális menedzsmentet épít ki, fejlesztő perifériákat hoz létre, finanszírozása diverzifikált, erős akadémiai bázisa van, s áthatja a vállalkozói kultúra. Közelebbről nézve egy kis létszámú, operatív irányító testület vezeti, mely az üzleti világ menedzserszemléletét és az akadémiai értékeket egyesíti. Feladata a stratégiai döntések meghozatala, a lehetséges külső források felderítése és a bevételek újraosztása, valamint az egyetemi infrastruktúra fejlesztése. Az üzleti partnerekkel és a helyi önkormányzattal, illetve a kormányzattal való együttmüködésben végzendő kutatás-fejlesztési és innovációs tevékenységre periférikus egységeket, pl. ipari, illetve üzleti parkokat, inkubátorházakat, az egyetemről kipörgetett cégeket, illetve start-up vállalkozásokat hoz létre, melyek kapcsán mátrix-típusú szervezeti modell alakul ki. Az ezekben a $\mathrm{K}+\mathrm{F}+\mathrm{I}$ egységekben folyó projektmunkákba a hallgatók is bekapcsolódnak, melyekből saját kutatásaik, start-up cégeik, avagy munkaeröpiaci karrierjük elindul, majd alumnusként visszaér az egyetemre újabb kutatási megrendelések formájában. A vállalkozói egyetem az elsődleges, normatív finanszírozás mellett másodés harmadlagos források bevonásával biztosítja financiális stabilitását, amely egyszerre
A vállalkozói vagy innovativ egyetem fö́ jellemzói, hogy erós és professzionális menedzsmentet épit ki, fejlesztó perifériákat hoz létre, finanszírozása diverzifikált, erós akadémiai bázisa van, sáthatja a vállalkozói kultúra. Közelebbról nézve egy kis létszámú, operativ irányító testület vezeti, mely az üzleti világ menedzserszemléletét és az akadémiai értékeket egyesíti. Feladata a stratégiai döntések meghozatala, a lehetséges külsó források felderitése és a bevételek újraosztása, valamint az egyetemi infrastruktúra fejlesztése. Az üzleti partnerekkel és a helyi önkormányzattal, illetve a kormányzattal való együttmúködésben végzendô kutatásfejlesztési és innovációs tevékenységre periférikus egységeket, pl. ipari, illetve üzleti parkokat, inkubátorházakat, az egyetemról kipörgetett cégeket, illetve start-up vállalkozásokat

hoz létre, melyek kapcsán mátrix-típusú szervezeti modell alakul ki. Az ezekben a $\mathrm{K}+\mathrm{F}+\mathrm{I}$ egységekben folyó projektmunkákba a hallgatók is bekapcsolódnak, melyekból saját kutatá-

saik, start-up cégeik, avagy munkaerópiaci karrierjük elindul, majd alumnusként visszaér az egyetemre újabb kutatási megrendelések formájában. 
felelősség és önállóság pénzügyi helyzete irányításában, s az egyetemi autonómia egy új formája. Az oktatói és kutatói bázis támogatja az üzleti szemléletet, mert az önálló, egyetemi forrásátcsoportosítások és az infrastrukturális fejlesztések jobb feltételeket teremtenek munkájukhoz, és biztosíthatják minden egység akadémiai értékeinek fennmaradását. Az egyetemi szervezeti kultúrát pedig áthatja a vállakozói szemlélet, amely vállalkozói közösséggé formálja az oktatók, kutatók, adminisztrátorok és hallgatók korábban szervezeti egységekre különült csoportjait (Hrubos, 2004).

Bár a vállalkozói egyetem modellje még nem általános, már felmerült egy „negyedik funkció” és az „elkötelezett egyetem” gondolata, oly jelentőssé és megkülönböztetővé vált a regionális elkötelezettség és beágyazódás, valamint a társadalmi felelősségvállalás szerepe a harmadik missziós küldetésen belül (Gál, 2016; Hrubos, 2018), amit a már említett négyes és ötös spirál modellek foglalnak keretbe. Az elkötelezett egyetem prioritása a helyi és regionális fókuszú oktatási és kutatási misszió, amely fejlesztő szerepet betöltve segíti elő a térség gazdaságfejlesztését és területi felzárkózását, valamint a közösség fokozott szolgálatát jelenti (Chatterton és Goddard, 2000; Gál, 2016; Holland, 2001). Ez az egyetem nagyfokú közösségi beágyazódását és szolgáltató funkciói megerősítését igényli régiójában. Előbbi az egyetemi oktatók aktív szerepvállalását jelenti a helyi-regionális hálózatokban, illetve a helyi döntéshozók és üzleti partnerek képviselöinek bevonását az egyetem saját döntéshozatali és szervezeti rendszereibe. Utóbbira példa lehet a regionális beiskolázáshoz és a diplomás pályakezdők megtartásához kötődő szolgáltatások; a rugalmas, élethosszig tartó tanulás stratégiai szintü támogatása; a regionális gazdasági és munkaerőpiaci igényekhez igazított képzési programok; a magas hozzáadott értékủ oktatáshoz való széleskörű hozzáférés biztosítása (Kálmán, 2012); az oktatás és kutatás közötti szorosabb kapcsolat, illetve a kutatási eredmények végfelhasználói iránti nagyobb felelősségvállalás (Chatterton és Goddard, 2000; Gál, 2016).

Ugyanakkor mindez az intézmény számára a városi és regionális gazdasági előnyök kiaknázását jelentheti; a helyi gazdasági és társadalmi fejlesztési igények, illetve kultúra ihlette innovációs kezdeményezésekhez vezethet; valamint a megerősödő intézményközi kapcsolatok alapján közös tudásplatformok létrehozását eredményezheti. Azaz a tudástermelés és -felhasználás, a gazdaság- és társadalomfejlesztő hatás erősen lokalizálttá válhat (Gál, 2016; Varga, 2004), ami élesen eltér a vállalkozói egyetem modelljének nemzetközivé tágított tevékenységi körétől.

Különösen releváns ez a kelet-közép-európai kis és közepes méretü egyetemek esetében, akiknek olyan kutatási irányokat érdemes kialakítaniuk, amelyek közvetlenül kötödnek a helyi gazdaság igényeihez. Ha pedig ezek komplex gazdaságpolitikai intézkedések és regionális gazdaságfejlesztő programok által támogatást kapnak, akkor leküzdhető a megfelelö gazdasági bázis hiánya (Gál, 2016; Varga, 2004). Az elkötelezett egyetem pedig kulcsszereplöje lehet a helyi fejlesztési koalícióknak, amik a szereplök közös érdekén, helyi identitásán, saját forrásain és kölcsönös kötelezettségvállalásán alapuló, célzott együttmüködések a helyi gazdaság fejlesztésére egy adott helyen és időben (Gál, 2016; Kálmán, 2012; Pálné, 2009).

\section{Egyetemi társadalmi felelősségvállalás}

Az elkötelezett egyetem koncepciójának egyik alapja az egyetemi társadalmi felelösségvállalás, azaz a university social responsibility (USR), melynek meghatározására számos definíció létezik a nemzetközi szakirodalomban. Jorge és Peña 15 év szakmai írásait összefoglaló tanulmányában több megnevezés elemzése után arra az összefoglaló definícióra jut, hogy akkor lesz egy egyetem társadalmilag felelős, ha: 
1. az oktatás tekintetében társadalmi, etikai és környezetvédelmi ügyeket emel be a tananyagaiba, hogy a fenntartható fejlödés elve az oktatás legfelsőbb szintjén is megjelenjen és az oktatás egy fenntarthatóbb társadalom alapjává válhasson (lásd az ENSZ Decade of Education for Sustainable Development és Principles for Responsible Management Education dokumentumait, illetve a Bolognai Folyamat célkitüzéseit)

2. a kutatás tekintetében a társadalom felé irányuló tudástranszfer által,

3. az irányítás tekintetében a helyes kormányzás és az elszámoltathatóság eljárásainak alkalmazásával, melyet a helyes kormányzás elveinek lefektetése, a társadalmi és környezetvédelmi ügyek beszámolási gyakorlatának kialakítása és a külső érdekhordozók egyetemi kormányzásban való nagyobb szerepvállalása kísér,

4. a közösségi szerepvállaláshoz kötődő tevékenységek tekintetében pedig azokat a közösségi tagság, a polgári értékek támogatása (pl. társadalmi igazságosság, méltányosság és diverzitás), az állampolgárságra való oktatás és a társadalmi-gazdasági környezethez való hozzájárulás alapján kell meghatározni (Jorge és Peña, 2017).

Az egyetemi társadalmi felelősségvállalás egy másik, igen megfontolt meghatározását Vallaeys (2014. 96.) nyújtja, aki szerint az „egy olyan egyetem modellje, amely földrajzi területéhez kötött, nyitott a párbeszédre, figyelembe veszi lokális és globális társadalmi és környezeti hatásait és aktívan támogatja a demokratikus módon előállított tudást mint egy közösségi és nem-kommercializálható terméket. Az egyetemi társadalmi felelősségvállalás az egyetemi közösséget folyamatos önvizsgálatra készteti feladatai episztemológiai horizontjai és utóhatásai tekintetében. Egy 'zöld' egyetem törődik az embereivel és környezetével, globális akadémiai diverzitásra törekszik, elutasítja a monopóliumokat és a tudás-előállítás sztenderdizálását, $\mathrm{s}$ bátorítja a fenntartható és méltányos tanulást és kutatást a tudás közösségeiben.” Végül hangsúlyozza, hogy „nincs jel arra, hogy egy ilyen egyetem hozzájárulása az emberiség általános kognitív és spirituális fejlődéséhez csekélyebb lenne, mint egy olyan egyetemi modellé, amely szerint a tudomány és a tudás kereskedelmi termék".

A magyar szakirodalomban Kerekes Sándor, Rechnitzer János, Reisinger Adrienn, Dános Zsolt és Bodorkós Barbara már foglalkoztak az egyetemi, illetve állampolgári társadalmi felelősségvállalás kérdésével. Reisinger és Dános (2015. 118.) megfogalmazása szerint a társadalmi felelősségvállalás arra utal, hogy „,az egyes szereplők nemcsak saját életükben vagy müködésük során hozott döntéseikért vállalják a következményeket, hanem a szükebb-tágabb környezetükben történő eseményekért is felelősséget vállalnak önként és nem kötelező tevékenységként". Véleményük szerint ez az elköteleződés áthathatja mind a három egyetemi missziót. Az oktatás területén kifejeződhet:

- a fenntartható fejlődés és a társadalmi felzárkóztatás egyetemi tananyagokba való beemelésében,

- a hallgatók környezettudatos és szociálisan érzékeny szemléletének kialakításában, illetve formálásában

- az esélyegyenlőséget előmozdító hallgatói ösztöndíjak és támogatások biztosításában (pl. fogyatékkal élőknek, hátrányos és halmozottan hátrányos helyzetüeknek),

- speciális szakkollégiumok létrehozásában,

- hallgatótámogatási szolgáltatások biztosításában (pl. mentorprogramok),

- kisebbségi nyelvek és kulturális ismeretek oktatásában,

- civil szervezetek tevékenységeinek kurzusokba való bevonásában (Reisinger és Dános, 2015).

A különféle társadalmi szereplőkkel közösen indított kutatási projektek (pl. akciókutatás a hallgatók helyi közösségi munkája során fejlesztett szociális kompetenciákról) 
(Bodorkós, 2010, idézi Reisinger és Dános, 2015), az akadémiai stáb és a civil szervezetek képviselőinek kapcsolatépítése konferenciákon és szakmai találkozókon, az egyetemi kutatók felmérései a térség társadalmi helyzetéről, illetve eredményeik beemelése az egyetemi stratégiába, a fenntartható fejlődés és a társadalmi esélyegyenlőség témájához kapcsolódó kutatások indítása, illetve szempontjainak érvényesítése az egyetemi kutatásokban mind konkrét javaslat az egyetemi társadalmi felelősségvállalás gyakorlati megvalósítására a második misszió területén (Kerekes, 2013; Reisinger és Dános, 2015).

Ami pedig a harmadik küldetést illeti, az egyetemi társadalmi felelösségvállalás megjelenhet az oktatók, kutatók és hallgatók önkéntes munkája és civil szervezetekben betöltött tisztsége nyomán, az esélyegyenlöség elvének alkalmazásában az egyetemi foglalkoztatás terén, a kulturális és sportintézményekkel való kapcsolattartásban és együttmüködési megállapodásokban, a helyi-regionális közösség tagjai számára tartott szakmai és gyakorlati előadássorozatokban, a fenntartható fejlődés elvének stratégiai szintre emelésében, illetve a fenntartható campus létrehozásában (Reisinger és Dános, 2015).

A három misszió ilyen megvalósítása által fejlődhetnek az oktatói, kutatói és hallgatói kompetenciák, növekedhet a kapcsolati és társadalmi tőke, fejlődhetnek az egyetem társadalmi kapcsolatai és a bizalom, feltárulhatnak a helyi-regionális társadalmi problémák és folyamatok, közelebb kerülhet a tudomány az emberekhez, megbecsültebbé válhatnak a kutatási eredmények, s terjedhetnek az önkéntesség és a fenntartható fejlödés eszméi (Rechnitzer és Reisinger, 2015; Reisinger és Dános, 2015).

\section{Harmadik misszió és társadalmi felelősségvállalás: néhány magyarországi egyetem példája}

Bár az egyetemi társadalmi felelősségvállalás hazai irodalma még szerény, Bander Katalin, Reisinger Adrienn és Dános Zsolt, Gál Zoltán, valamint Komlósi László tanulmányai információval szolgálnak a magyarországi egyetemek harmadik misszió keretében megvalósított társadalmi felelősségvállalásának gyakorlatáról.

Bander Katalin 2011-ben az E3M kutatás magyarországi megismétlése során az intézményi honlapok vizsgálata nyomán megállapítja, hogy amennyiben egy intézménynél megjelenik a harmadik küldetés, ott jelen van a társadalmi szerepvállalás valamilyen formája is (Bander, 2011). Kutatása eredményeit a harmadik misszió és a társadalmi felelősségvállalás mérési lehetőségeiről szóló alfejezetben ismertetem.

Reisinger Adrienn és Dános Zsolt a társadalmi felelősségvállalás megjelenését vizsgálták több felsőoktatási intézmény stratégiai dokumentumaiban. Tanulmányukban előbb összefoglalják az egyetemek társadalmi felelősségvállalása alá tartozó tevékenységek körét, majd a Miskolci Egyetem, a Kaposvári Egyetem és a győri Széchenyi István Egyetem társadalmi felelősségvállalás szellemében az elmúlt évek intézményfejlesztési terveiben meghirdetett, illetve már megvalósított tevékenységeit ismertetik. Megállapítják, hogy a társadalmi felelősségvállalás elvei egyre hangsúlyosabban szerepelnek az egyetemi stratégiákban, s egyre bővülö körü aktivitásokat jelölnek, amelyek elsősorban az egyetemek regionális szerepvállalását erősítik hol a társadalmi felzárkóztatás prioritásával (Miskolci Egyetem), hol az esélyegyenlőség széles spektrumú támogatásával (Kaposvári Egyetem), hol pedig a helyi-regionális gazdaságfejlesztő szerep hangsúlyozásával.

Ezek közül kiemelendő a Kaposvári Egyetem 2012 óta megvalósuló sokrétủ társadalmi elkötelezettséget bizonyító tevékenysége: ingyenesen nyújtott szakértői munka és képzés a közmunkaprogramok kidolgozásában és a Minden gyermek lakjon jól program tervezésében, illetve lebonyolításában, pedagógiai és vidékfejlesztési szaktanácsadás a leghátrányosabb helyzetű kistérségek fejlesztési programjának kidolgozásában, roma 
szakkollégium létrehozása és müködtetése, valamint vállalkozási és gazdálkodási ismeretek nyújtása a térség gazdálkodói számára. Aktív együttmüködésben áll a térség civil szereplőivel, akikkel különböző szakterületeken működik együtt képzési és kapcsolódó szakmai feladatok ellátásával, különösen a Gazdaságtudományi és a Pedagógiai Kar szerepvállalásával. Például a Tamási és Simontornya Városkörnyéki Önkormányzatok Többcélú Kistérségi Társulásával 2011-2012-ben zajlott együttmüködés során kiterjesztették az egyetem alaptevékenységeit a kistérség felé, elősegítették a helyi fejlesztések megvalósítását, valamint a kistérség társadalmi hálózatokhoz való kapcsolódását. $A$ felsőoktatás és a kistérségek partnerségi programja keretében a két kar kutatást végzett a térségben, valamint hallgatói aktívan bekapcsolódtak a kistérség társadalmi felemelkedését szolgáló tevékenységekbe. Ezek során szociológiai felmérést végeztek, konferenciát szerveztek a hatékony kapcsolati hálók kiépítése érdekében, szaktanácsadással segítették a kistérségi területi tervek elkészítését, országos jó gyakorlatokat mutattak be a kistérségi gazdaságfejlesztés lehetőségeiről (pl. helyi termékek és pénz, alternatív energiaforrások közösségi felhasználása, helyi KKV-k fejlesztése, szociális gazdaság), illetve pályázati és projektmenedzselési segítséget nyújtottak.

A program nyomán a Kaposvári Egyetem stratégiai céljai közé emelte a hátrányos helyzetű vidéki térségekben élő tehetséges fiatalok tanulmányainak támogatását, az ilyen térségek fejlesztését és a társadalmi kohézió erősítését. 2016-ig terjedő akciótervében meghatározta az ilyen célú egyetemi programok és elért személyek 16-16\%-os növelését, valamint a szociális képzésben részt vevő szakemberek számának 129-ről 140 főre való emelését. Továbbá számos egyedi tevékenységet kezdeményezett a 2010 óta tartó időszakban, például lehetőséget biztosított hallgatói önkéntes segítő tevékenységeire, mentorprogramot indított hátrányos helyzetü, továbbtanulni szándékozó jelentkezők számára, megalapította a roma szakkollégiumot, illetve a Pedagógiai Kar komplex támogatási programot indított a halmozottan hátrányos helyzetü gyermekek tehetséggondozása érdekében. Utóbbi egység oktatási missziója keretében megemlítendők gyógypedagógiai és különféle terápiás képzései, az előbbihez kapcsolódó romológiai specializáció, gyakorlóiskolái esélyegyenlőséget támogató tevékenységei, valamint az egyetem Lovasakadémiájának speciális képességfejlesztő és terápiás tevékenysége. Mindebben pedig az egyetem egyes egységeinek segítségére voltak olyan helyi, regionális, illetve országos partnerek, mint a Somogy Megyei Önkéntes Centrum, a megyei fejlesztő módszertani központok és alapítványok, számos TÁMOP pályázat, valamint az illetékes minisztériumok. Ugyanakkor hátrányként kiemelendő, hogy a felsorolt sokféle tevékenység csupán egyes szervezeti egységekhez köthető, s az egyetem a vizsgált időszakban nem rendelkezett egy átfogó, egységes társadalmi felelősségvállalási stratégiával. Bár a fogalom megjelent az aktuális intézményfejlesztési tervében, csak mellékes szerepet töltött be a kormányzati és gazdasági kapcsolatok prioritásával szemben. Az egyetem társadalmi felelősségvállaláshoz köthető szerteágazó tevékenységeinek keretbe foglalása és intézményesülése valószínüleg a 2015 óta eltelt időszakban realizálódik (Reisinger és Dános, 2015).

A szerzőpáros a győri Széchenyi István Egyetem vonatkozásában kiemeli, hogy a 2007-2015 közötti időszakban stratégiai dokumentumai csak közvetetten tartalmazták a társadalmi felelösségvállalás kérdését, s az nem a társadalmi felzárkóztatás, hanem a térségben megvalósított kulturális, sport- és tudománynépszerüsítő tevékenységein keresztül, egyes oktatott kurzusai tartalmában és szociális képzésein belül, illetve alapítványi támogatások és infrastrukturális akadálymentesítés formájában valósult meg. Realizálásuk is inkább egyének közötti, illetve egyének és intézmények közötti, mintsem intézményközti kapcsolatokban valósul meg, s várat magára egy tudatos, részletesen kidolgozott és egységesen érvényes szociális misszió meghirdetése és intézményesítése. Kutatásuk értékeléseként végül megállapítják, hogy a társadalmi felelősségvállalás a három vizsgált egyetem esetében „stratégiaként még csak részben jelent meg, de a 
regionális szerepvállaláshoz kapcsolódó feladatok bővülésével a társadalmi felelősségvállalás szegmensei [...] egyre erőteljesebben körvonalazódnak" (Reisinger és Dános, 2015. 131.).

Gál Zoltán pedig a Pécsi Tudományegyetem mint „elkötelezett szolgáltatóegyetem” társadalmi felelősségvállalás keretében a közelmúltban végzett tevékenységeit értékeli. Az egyetem két nagyszabású városi-regionális projektben vett részt, az egyik a Pólus Program, a másik az Európa Kulturális Fövárosa 2010 projekt. A Pólus Program estében a PTE meghatározó szerepet játszott a tervezésben, a megvalósításban és az irányításban, elsősorban a projekt egészségipari és környezetipari pilléreiben. Az előbbi a PTE ÁOK egészségügyi, kiemelten mozgásszervi rendellenességeket kezelő szolgáltatásaiban; kapcsolódó gazdasági funkciókban, mint például orvosi müszerek, implantátumok és protézisek gyártása; valamint regenerációs és rekreációs egészségjavító szolgáltatásokban nyilvánult meg. Utóbbi pedig a vonzóbb városi környezet kialakításához és az alternatív energiaforrások kihasználásához kötődő egyetemi tevékenységekben realizálódott (Gál, 2016; Lux, 2010). Az egyetemi kapcsolatokból fakadó fejlesztési potenciál kihasználását és a hoszszú távon is fenntartható gazdaságfejlesztési hatásokat viszont a program finanszírozási szerkezetének megváltozása, a klaszterekben aktív szerepet vállalni képes cégek hiánya és a helyi vásárlóerö összezsugorodása nem tette lehetővé.

Az Európa Kulturális Fövárosa 2010 projektben viszont már a kultúraipar területén végzett kiemelkedő munkát a Pécsi Tudományegyetem. Szoros együttműködésben a várossal és az európai uniós projekt vezetésével, részt vett a projekt megszervezésében, a kulturális események megrendezésében, az új kulturális-tudományos negyed kiépítésében, illetve funkcióval való megtöltésében, amikor a Zsolnay-negyedbe költöztette Művészeti Karát és egyéb oktatási, közösségi és kulturális tevékenységeit, valamint új tudásteret hozott létre a Dél-Dunántúli Regionális Könyvtár és Tudásközponttal. Mindebből kitünik, hogy az egyetem katalizátori szerepet játszott a hálózatépítésben

Az egyetem két nagyszabású városi-regionális projektben vett részt, az egyik a Pólus Program, a másik az Európa Kulturális Fóvárosa 2010 projekt. A Pólus Program estében a PTE meghatározó szerepet játszott a tervezésben, a megvalósításban és az irányításban, elsósorban a projekt egészségipari és környezetipari pilléreiben. Az elóbbi a PTE ÁOK egészségügyi, kiemelten mozgásszervi rendellenességeket kezeló szolgáltatásaiban; kapcsolódó gazdasági funkciókban, mint például orvosi múszerek, implantátumok és protézisek gyártása; valamint regenerációs és rekreációs egészségjavitó szolgáltatásokban nyilvánult meg. Utóbbi pedig a vonzóbb városi környezet kialakitásához és az alternativ energiaforrások kihasználásához kötôdó egyetemi tevékenységekben realizálódott (Lux, 2010, idézi Gál, 2016). Az egyetemi kapcsolatokból fakadó fejlesztési potenciál kihasználását és a hosszú távon is fenntartható gazdaságfejlesztési hatásokat viszont a program finanszirozási szerkezetének megváltozása, a klaszterekben aktív szerepet vállalni képes cégek hiánya és a helyi vásárlóeró összezsugorodása nem tette lehetóvé. 
és a partneri együttműködés előmozdításában. Gál elemzése végén azonban kiemeli az egyetem két projektben vállalt, közösséget szolgáló tevékenységei sikerét nehezítö tényezőket is: a megfelelö gazdasági bázis és az erős vállalati szektor hiányát, a felvevőpiac korabeli összezsugorodását, a helyi cégek elégtelen gazdasági erejét és a piacosítható egyetemi kutatások kritikus tömegének hiányát (Gál, 2016).

\section{A harmadik misszió és a társadalmi innováció mérési lehetőségei: hazai kutatások}

Miként mérhető a harmadik missziós tevékenységek eredményessége? Az egyetemek nemzetközi rangsorainak többsége nem veszi figyelembe a harmadik küldetéshez köthető egyetemi szerepvállalást (Hrubos, 2011; Hrubos, 2013), azonban az Európai Egyetemi Szövetség 2010-re elkészült U-Map mapping rendszere éppen az intézményi sokféleséget kívánja kihangsúlyozni, azonosítva azok fö típusait tényleges tevékenységeik alapján. A vizsgált dimenziók között megjelenik a harmadik misszió, illetve annak néhány eleme: a tudástranszfer, a hallgatók összetétele és a regionális elköteleződés. Az U-Mapre épülve született meg az U-Multirank, mely az oktatás és tanulás, a kutatás és a nemzetközi orientáció dimenziói mellett megtartja a tudástranszfer és a regionális elköteleződés szempontjait is. 31 indikátoron keresztül térképezi fel az európai egyetemek teljesítményét, s lehetővé teszi a hasonló szakterületen müködő és hasonló küldetést vállaló intézmények felhasználóbarát összehasonlítását (Hrubos, 2011; Hrubos, 2014). Egyediségét erősíti, hogy vizsgálati dimenziói közé beemeli a nem egyetemi szektort és a tudományterületek széles körét (Hrubos, 2013).

A nemzetközi rangsoroknál azonban informatívabbak a nemzeti felmérések. Az Európai Bizottság E3M kutatását, amely 2008 és 2011 között zajlott a harmadik misszió vizsgálati dimenzióinak és indikátorainak meghatározására, s mely aztán az U-Map elkészítésének alapja lett (Hrubos, 2013), Magyarországon a Budapesti Corvinus Egyetem Hrubos Ildikó vezette kutatócsoportja adaptálta 2010-2012 között. Céljuk az volt, hogy

\section{Miként mérhetố a harmadik} missziós tevékenységek eredményessége? Az egyetemek nemzetközi rangsorainak többsége nem veszi figyelembe a harmadik küldetéshez köthetố egyetemi szerepvállalást (Hrubos, 2011; Hrubos, 2013), azonban az Európai Egyetemi Szövetség 2010-re elkészült U-Map mapping rendszere éppen az intézményi sokféleséget kivánja kihangsúlyozni, azonosítva azok fó típusait tényleges tevékenységeik alapján. A vizsgált dimenziók között megjelenik a

harmadik misszió, illetve annak néhány eleme: a

tudástranszfer, a hallgatók összetétele és a regionális elkötelezôdés. Az U-Mapre épülve született meg az U-Multirank, mely az oktatás és tanulás, a kutatás

és a nemzetközi orientáció dimenziói mellett megtartja a tudástranszfer és a regionális elkötelezódés szempontjait is. 31 indikátoron keresztül térképezi fel az európai egyetemek teljesitményét, s lehetôvé teszi a hasonló szakterületen múködó és hasonló küldetést vállaló intézmények felhasználóbarát összehasonlitását (Hrubos, 2011; Hrubos, 2014). 
a magyarországi felsőoktatási intézmények sokféleségének természetét tevékenységeikre fókuszálva, több szempontból, s rendszerbe foglaltan tárják fel, ám csupán azok milyenségére, nem pedig minőségére koncentrálva. Ezáltal az intézmények jellemző csoportjait állították fel mapping eljárással és klaszterelemzéssel. Alapvetően az U-Map dimenzióit és indikátorait használták, ám csak olyan mutatókat vettek figyelembe, amelyek vagy hivatalos és teljes körü adatforrásokból származtak, vagy ellenőrizhetö survey jellegü adatgyűjtési eredményekből. Továbbá a tudástranszfer és regionális elkötelezettség dimenzióban részleges adathiány miatt kevés indikátort szerepeltethettek, míg az oktatás és tanulás, illetve a hallgatók összetétele szempontjából többet, mint az U-Map. Ugyanakkor sajátos, kontextuális változókkal is kibővítették vizsgálódásukat, így például az intézményi honlapok szerinti vállalt küldetések vizsgálatával, ami pótolni próbálta a regionális elkötelezettség dimenzió említett adathiányát (Hrubos, 2011).

A harmadik misszió vizsgálatakor az E3M projekt három vonatkozó dimenzióját vették alapul: a folyamatos tanulás megvalósulását (nem-hagyományos hallgatói csoportok felsőoktatásba való bejutása), a technológiatranszfer-innováció-oktatási-kutatási partnerséget, valamint a társadalmiszerepvállalás-szolgáltatások szempontját. Megállapították, hogy a felsőoktatási intézmények 90\%-ánál megjelenik a harmadik küldetés valamilyen formája a küldetésnyilatkozatokban, s 58\%-uknál ez több dimenzióban is tetten érhetö. A vizsgálandó első dimenzió tekintetében $73 \%$-uk fontosnak tartja a folyamatos tanulás támogatását, ugyanakkor ez inkább a nagyobb hallgatói létszámú, szélesebb képzési profilú főiskolákra (pl. Kecskeméti Főiskola) és a széles profilú, de nem klasszikus szakmai összetételü egyetemekre jellemző (pl. SZIE). A nem hagyományos képzési formák, azaz a képzési formák fokozott diverzifikációjának támogatása a vizsgált intézmények több mint felére jellemző (Bander, 2011).

A technológiatranszfer-innováció-oktatási-kutatási partnerség az intézményi küldetések kétharmadánál megjelenik, ám a kutatás-fejlesztés tevékenységet ennél kevesebben nevezték meg feladatként, $\mathrm{s}$ a dimenzió egyes elemei is eltérö mértékben hangsúlyosak az egyes intézménytípusoknál. Ez a dimenzió leginkább a szélesebb képzési profilú és nagy létszámú főiskolákra (a $\mathrm{K}+\mathrm{F}+\mathrm{I}$ és oktatási partnerség azonos hangsúlyával), a föként gazdasági és társadalomtudományi képzést nyújtó kis létszámú magánfőiskolákra (az oktatási partnerség hangsúlyával), illetve a széles profilú, de nem-klasszikus szakmai összetételü egyetemekre (a $\mathrm{K}+\mathrm{F}+\mathrm{I}$ partnerség hangsúlya), avagy a klasszikus egyetemekre (azonos hangsúly az oktatási és K+F+I partnerségen) jellemző (Bander, 2011; Horváth, 2011).

A társadalmi szerepvállalás dimenzióját tekintve amennyiben egy intézménynél megjelenik a harmadik misszió, ott jelen van a társadalmi szerepvállalás valamilyen formája is (Bander, 2011). Az E3M projekt dimenzióit tekintve a társadalmi szerepvállalás és szolgáltatások területén a felsőoktatási intézmények klasztertípusaik szerint különböző szintü régiók, azaz város, megye, régió, ország, határon túli magyarlakta területek, illetve Közép-Kelet-Európa részeként tekintenek magukra, mely meghatározza társadalmi tevékenységeik és szolgáltatásaik hatókörét (E3M: Régiótudat). Bander az előbbi példájaként megemlíti az intézmény régiótudata által kijelölt terület kulturális és müvészeti életében való aktív szerepvállalást és a hagyományőrzést (E3M: Kulturális Misszió), mely a magyarországi felsőoktatási intézmények kétharmadára jellemző. Ugyanakkor a szolgáltatások körében a képzési profilokhoz kapcsolódó tevékenységek, így például a gyógyítás és a hátrányos helyzetü csoportok rendszeres segítése (E3M: Szociális Misszió), mely 11 intézményre jellemzö, továbbá a környezettudatos szemlélet terjesztése vagy a fenntartható fejlődés alapjait megteremtő gazdálkodás népszerüsítése jelenik meg (E3M: Környezetvédelem), bár ez utóbbi kettő akkor még csak kevés magyar felsőoktatási intézményre jellemző. Ezek azonban csak az intézmények külső társadalmi környezete felé irányuló tevékenységek, az E3M projekt és Bander is külön kezeli az intézmények hallgatóiknak nyújtott szolgáltatásait (Bander, 2011). 
A harmadik missziós tevékenységeket mérő indikátorok problematikájával foglalkozik Kotosz, Lukovics, Molnár és Zuti is, akik a harmadik, illetve negyedik generációs egyetem regionális gazdasági hatásainak méréséről írnak (Kotosz, Lukovics, Molnár és Zuti, 2015; Kotosz, Lukovics és Zuti, 2016). Ök a harmadik küldetést az egyetemek tudás és egyéb képességeket generáló, hasznosító, alkalmazó és kiszolgáló tevékenységeiként tekintik, amelyek az egyetem falain kívülre irányulnak, s a gazdasági és társadalmi szereplőkkel való közvetlen kapcsolatokon keresztül valósulnak meg. Kiemelik, hogy tisztázni szükséges a kutatás mint második, azaz intézményi indíttatású, és harmadik, azaz külső fél által kezdeményezett küldetését, illetve hogy rendkívül nehéz különválasztani és mérhetővé tenni az egyes küldetések gazdasági hatását, mert az egyetemeknek nem állnak rendelkezésére megfelelő információs rendszerek ezek kezelésére. A harmadik missziós tevékenységek hatásának mérése pedig azért metodológiai kihívás, mert nehéz mennyiségileg meghatározni azokat. Számos nemzetközi próbálkozás is történt ez irányban, melyek különféle dimenziókban és indikátorokkal próbálták megragadni és mennyiségileg mérhetővé tenni e tevékenységek mivoltát és eredményeit, de a szerzők szerint ezen indikátorok gyakorlati haszna kérdéses, például a mérési egységek hiánya vagy összehasonlíthatatlansága miatt, vagy mert eleve nehéz elkülöníteni az egyes missziók hatásait (Kotosz és mtsai, 2015).

Ugyanerre jutott a szerzőcsoport egyik tagja, Molnár Gabriella is, aki a Szegedi Tudományegyetem saját modelljét mutatja be, ami 2011 óta gyüjtött VIR adatok alapján, öt cél és kilenc indikátor mentén méri a három küldetés hatásait. A harmadik misszió tekintetében vizsgálja a technológia transzfer, a tanácsadás, a spin-off és start-up cégek, az egyetem-ipar-kormányzat kapcsolatai, az egyetemi létesítmények kereskedelmi hasznosítása, illetve az egyetem társadalmi szerepvállalásának növelése céljával indított tevékenységeket, melyekhez számos indikátort határoz meg. Ezek részben a nemzetközi szakirodalomból, részben a szerzőtől származnak, s olyan elemei vannak, mint például a társadalmi szerepvállalást jellemző kulturális események száma, azok belső és külső látogatóinak száma, a sajtómegjelenések száma, a társadalmi felelősségvállalást támogató egyetemi események száma vagy a tudásdisszeminációs programok száma (Molnár, 2015). A szerzőcsoport végül megállapítja, hogy bár rendelkezésre állnak komplex módszertani eszözök és indikátor-rendszerek a harmadik misszió közvetlen és közvetett hatásainak mérésére, ám ezek a rövid távú hatások mérésére képesek, míg a hosszú távúak mérése, különösen az indukált, vagy katalitikus hatásoké, továbbra is megoldatlan probléma (Kotosz és mtsai, 2015).

A társadalmi innovációk mérése már a négyes spirál modell mentén müködő elkötelezett egyetem fogalmához kapcsolódik. Varga Krisztina tanulmányában előbb megadja a társadalmi innováció fogalmát és jelentőségnövekedésének okait, majd mérése módjáról értekezve felvázol egy saját mérési modellt. A társadalmi innováció meghatározása szerint „,a közösség jól-létét növelő, a társadalomban felmerülő kihívások kezelését segítő folyamat”, amely a „társadalomban megjelenő szükségletek kielégítését eredményezi új, vagy újszerü együttmüködések, struktúrák mentén" (Varga, 2017. 505.). Az Európai Unió Horizon 2020 programja szerint olyan „új, az eddigi gyakorlattól eltérő szemlélet-, megközelítési mód, paradigma, termék, eljárási folyamat, gyakorlat, amely a társadalomban felmerülő problémák és szükségletek megoldását célozza meg, miközben új értékek, attitüdök, új társadalmi kapcsolatok, esetleg új struktúrák jönnek létre" (Nemes és Varga, 2015; Varga, 2017. 505.). A társadalmi innováció révén Varga szerint lehetőség nyílik az életminőség és az élettartam fejlesztésére, s a jóllét tényezői közé a jövedelmi viszonyokon túl a biztonságérzetet, az önbecsülést és a kapcsolati szükségleteket is beleérti. A társadalmi innováció eredménye pedig nemcsak a felmerülö szükségletek, illetve igények kielégítése lesz, hanem a társadalom cselekvőképességének fokozása is (Czakó, 2000; Varga, 2017).. 
A társadalmi innováció aktualitását a technikai innovációhoz füződő szoros kapcsolata indokolja, hiszen az előbbi egyszerre közege és kerete a technikai innováció megvalósításának, illetve a kettő egymás komplementer folyamatai. Gábor Dénest idézve Varga emlékeztet, hogy a társadalmi innováció egy ,átfogó keretprogram, ami [...] az innovációk összességét ellenőrző és szabályozó “reform"” (Gábor, 1970, idézi Varga, 2017. 506.), majd kiemeli, hogy a periférikus területek felzárkóztatásában szerepet kell kapniuk a helyi közösség szintjén megjelenő újító ötleteknek és társadalmi innovációs tevékenységeknek is. Ezek a technikai innovációkkal együtt kezelhetik a helyi társadalmi kihívásokat, hozzájárulhatnak a gazdaság fejlődéséhez és a versenyképesség növekedéséhez. Sőt az ilyen céllal indított ,új együttmúködések, kapcsolódások és szervezeti formák [...] önmagukban is innovációként funkcionálhatnak" (Varga, 2017. 506.).

Azonban a társadalmi innováció helyi-regionális versenyképesség-növelő hatását mérni is szükséges. A társadalmi innováció alapvetően három megvalósítási formában jelentkezhet, amint azt az Európai Bizottság 2013-as vizsgálata megállapította: alulról szerveződő, civil szervezetek bevonásával megvalósuló újítás (mikroszint), a közösségi szükségletekre a társadalmi értékek alapján adott válaszreakció (mezoszint), valamint a társadalom megújítását, illetve átalakítását eredményező folyamat (makroszint). Varga szerint mindhárom szint mérése, a szintek közti kapcsolatok és kölcsönhatások feltárása és a keretfeltételek meghatározása is szükséges. Továbbá az innovációs folyamatokra rendszerként kell tekinteni, amit a kiindulási feltételek azonosítása, azaz a bementi tényezők, a vizsgálandó innovatív tevékenységek átalakító folyamata, azaz a transzformációk, valamint az innováció eredményei, azaz a kimeneti eredmények jellemeznek. Ezekhez indikátorokat kell rendelni, de azokat el kell különíteni az innovációt ösztönző, illetve az innovációs folyamat eredményeit mérő kategóriákba. Ismét felmerül a mutatók definiálásának és mérhetőségének kérdése, valamint a lehetséges indikátorok nagy száma. Utóbbit változócsoportokba sorolással, illetve faktoranalízis nyomán való redukálással javasolja megoldani. Az előbbire nézve pedig felhívja a figyelmet az „újdonság, a társadalmi igény, a társadalom fejlsztése, a szektorsemlegesség és a megjelenés szintének" szempontjaira, melyek meg kell hogy határozzák a mutatók azonosítását. Továbbá figyelni kell a rövid és hosszú távú hatásokra, a kiugró adatok kezelésének szükségességére, a multikollinearitás szürésére és a „több jobb” feltevés helyességére (Varga, 2017. 512.).

Mindezek alapján Varga megállapítja, hogy egy olyan ,integrált modellre van szükség, amely képes komplex módon vizsgálni az adottságokat (keretfeltételeket), a szervezeti tevékenységeket és az eredményeket", továbbá magyarázatot tud adni az összefüggésekre, az interakciók kölcsönhatásaira, a három szint közti kölcsönös függőségekre és összefüggésekre (Varga, 2017. 513.). Végül az Európai Bizottság TEPSIE-Growing Social Innovation projektjének ajánlásában megjelenő modellt javasolja alkalmazásra, amely bár a makroszintü mérésekre irányul, de adoptálható a mezo- és mikroszintekre is szervezeti szintű esettanulmányok készítésével és elemzésével, illetve a településszintű kezdeményezések vizsgálata révén.

A mérés három elemzési területe az innovációt stimuláló keretfeltételek, az innovációt végrehajtó „vállalkozók” motivációi, azok tevékenysége, valamint a konkrét területi eredmények és hatások. A vállalkozói tevékenység az innovátor, a civil társadalom, illetve az egyéb, informális csoportok vagy egyének tevékenysége; az innovációs folyamat lineárisan valósul meg a javaslatok megfogalmazása, a minta létrehozása és az innováció megvalósítása nyomán. A modell az innovációs folyamatot nyílt rendszerben lezajlónak látja, azaz a keretfeltételek nem befolyásolhatók közvetlenül, ám szabályozó szereppel bírnak a folyamatra (pl. politikai, erőforrás-alapú, társadalmi és intézményi tényezők). Az eredmények, mind a szervezeti, mind a társadalmi szintüek, a társadalmi újítás színterei, és kifejezik a keretfeltételek, a vállalkozói tevékenység és a kiinduló motivációk kölcsönhatásainak befolyását. A folyamat elemzése során pedig különösen 
fontos a visszacsatolási hurkok feltárása, hiszen az innovációs folyamat eredménye megnöveli a cselekvőképességet, s újabb innovációkat generálhat (Varga, 2017).

\section{Összegzés}

Tanulmányomban a doktori kutatási témámhoz legközvetlenebbül kapcsolódó felsőoktatás-kutatási fogalmak és jelenségek összefoglaló bemutatására vállalkoztam az általam eddig megismert hazai szakirodalom alapján. A magyarországi vidéki egyetemek helyi-regionális közösségi elköteleződése jegyében indított harmadik missziós tevékenysége a gazdasági és társadalmi partnereik és az érdekhordozók felé sokféle tudástranszferés tudásdiffúziós tevékenységben nyilvánul meg. Kutatásomban ezek céljait, megvalósításuk módját, eredményeit és nehézségeit, valamint az érdekhordozókra kiváltott hatásait kívánom megvizsgálni néhány kiválasztott intézmény és intézményi cél, különösen a hallgatói létszámnövelés tekintetében.

Ehhez bemutattam a harmadik misszió fogalmát, stratégiai fontosságúvá válásának okait és változatos céljait, a működési keretét nyújtó négyes és ötös spirál modelljeit, valamint a felsőoktatási intézmények közelmúltban elindult szerepbővülése nyomán kialakult vállalkozói egyetem és elkötelezett egyetem koncepcióját. A társadalmi beágyazódás fontosságának növekedése kapcsán ismertettem az egyetemi társadalmi felelősségvállalás fogalmát és megvalósításának lehetőségeit a három küldetésen keresztül, ami rávilágított arra, hogy a társadalmi elköteleződés és szerepvállalás a harmadik misszión belül, de afelett is értelmezendö. Hogy gyakorlati megvalósulását példákkal is illusztráljam, a szakirodalom nyomán röviden bemutattam néhány magyarországi egyetem harmadik missziós, illetve egyetemi társadalmi felelősségvállás szellemében a közelmúltban végzett tevékenységét, azok eredményeit, korlátait és továbbfejlesztésének lehetőségeit.

Mindezek arra mutatnak, hogy az egyetemek társadalmi elköteleződése egyre hangsúlyosabb stratégiai dokumentumaikban,
A mérés három elemzési területe az innovációt stimuláló keretfeltételek, az innovációt végrehajtó „vállalkozók” motivációi, azok tevékenysége, valamint a konkrét területi eredmények és hatások. A vállalkozói tevékenység az innovátor, a civil társadalom, illetve az egyéb, informális csoportok vagy egyének tevékenysége; az innovációs folyamat lineárisan valósul meg a javaslatok megfogalmazása, a minta létrehozása és az innováció megvalósítása nyomán. A modell az innovációs folyamatot nyílt rendszerben lezajlónak látja, azaz a keretfeltételek nem befolyásolhatók közvetlenül, ám szabályozó szereppel birnak a folyamatra (pl. politikai, eróforrás-alapú, társadalmi és intézményi tényezók). Az eredmények, mind a szervezeti, mind a társadalmi szintúek, a társadalmi újítás szinterei, és kifejezik a keretfeltételek, a vállalkozói tevékenység és a kiinduló motivációk kölcsönhatásainak befolyását. A folyamat elemzése során pedig különösen fontos a visszacsatolási hurkok feltárása, hiszen az innovációs folyamat eredménye megnöveli a cselekvóképességet, s újabb innovációkat generálhat (Varga, 2017). 
és rendkívül színes, valamint bővülő körü tevékenységekben realizálódik. Ezek szükséges alapja a helyi és térségi civil, gazdasági és politikai szereplőkkel való hatékony és folyamatos együttműködés, s célközönsége lehet mind az egyetem falain kívüli helyi-térségi közösség, mind a falakon belüli hallgatóik. Eredményeik megnyilvánulhatnak a régió gazdaságfejlődésében, társadalmi kihívásainak kezelésében, a kulturális, sport- és tudományos élet felpezsdülésében, végeredményben a térség versenyképességének növekedésében. Minden ilyen jellegü egyetemi kezdeményezés és fenntartott tevékenység növeli az egyetemek súlyát régiójukban, s erősíti az intézmény identitását a választott regionális szinten (város, kistérség, régió, ország, EFT).

A harmadik missziós és társadalmi felelősségvállalás jegyében végzett egyetemi tevékenységek viszont stratégiai keretbe foglalást, minden szervezeti egységre kiterjedő érvényességet és intézményesítést igényelnek, amely során a helyi és térségi partnerekkel való együttmüködés folyamatossá válik és megerősödik az egyéni, a csoport és az intézményközi szinten is. A finanszírozási és emberierőforrás-feltételek biztosításán, valamint a folyamatos és megfelelő kommunikáció igényén túl a harmadik miszsziós tevékenységek sikerességéhez szükséges azok mérése is. Ez azonban számos nehézséget felvet, mint például az egyes missziók gazdasági és társadalmi hatásainak elkülönítése, a megfelelő indikátorok megállapítása, operacionalizálása és összehasonlíthatósága, vagy a hosszú távú, katalitikus hatások kimutatása. Mégis születtek már európai szintü és hazai megoldási modellek

Mindezek arra mutatnak, hogy az egyetemek társadalmi elkötelezódése egyre hangsúlyosabb stratégiai dokumentumaikban, és rendkivül szines, valamint bôvüló körú tevékenységekben realizálódik. Ezek szükséges alapja a helyi és térségi civil, gazdasági és politikai szereplókkel való hatékony és folyamatos együttmúködés, s célközönsége lehet mind az egyetem falain kivüli helyi-térségi közösség, mind a falakon belüli hallgatóik. Eredményeik megnyilvánulhatnak a régió gazdaságfejlódésében, társadalmi kihívásainak kezelésében, a kulturális, sportés tudományos élet felpezsdülésében, végeredményben a térség versenyképességének növekedésében. Minden ilyen jellegú egyetemi kezdeményezés és fenntar-

tott tevékenység növeli az egyetemek súlyát régiójukban, s erôsíti az intézmény identitását a választott regionális szinten

(város, kistérség, régió, ország, EFT). is, amelyek részletes megismerése és adaptálása kiindulópontot jelenthet saját kutatásom számára is.

Ugyanakkor a szakirodalom tanulmányozása során felmerült a kutatási téma néhány további releváns aspektusa, amit a jövőben szükségesnek tartok részletesen megismerni. Ilyenek az egyetemek sokféle és egymással összefüggő regionális hatásai, a hálózatos kapcsolatok elméletei, a tanuló régió és a civil kutatás koncepciói, valamint a hallgatók aktív bevonása az egyetemek társadalmi szerepvállalásához kapcsolódó tevékenységekbe. 


\section{Irodalom}

Bander Katalin (2011). Vállalt küldetések az intézményi honlapok alapján. In Hrubos Ildikó (szerk.), NFKK Füzetek 8. Mühelytanulmányok: A felsöoktatási intézmények föbb típusai tevékenységük és vállalt missziójuk szerint. Nemzetközi piacorientáció, korszerü intézményi menedzsment. 58-88. Budapest: Budapesti Corvinus Egyetem Közgazdaságtudományi Kar NFKK, Aula Kiadó Kft.

Barakonyi Károly (2009). Bologna felülnézetben. In Barakonyi Károly (szerk.), ,Bologna Hungaricum”. Diagnózis és terápia. 18-92. Budapest: Új Mandátum Könyvkiadó.

Carayannis, E. G. \& Campbell, D. F. J. (2012). Mode 3 Knowledge Production in Quadruple Helix Innovation Systems. Twenty-first-Century Democracy, Innovation and Entrepreneurship for Development. SpringerBriefs in Business. New York: Springer-Verlag. DOI: 10.1007/978-1-4614-2062-0

Carayannis, E. G., Grigoroudis, E., Campbell, D. F.J., Meissner, D. \& Stamati, D. (2018). The ecosystem as helix: an exploratory theory-building study of regional co-opetitive entrepreneurial ecosystems as Quadruple/Quintuple Helix Innovation Models. $R \& D$ Management, 48(1), 48-162. DOI: 10.1111/ radm. 12300

Carrión, A., Garcia-Gutiérrez V.R., Bas M.C \& Carot J.M. (2012). A new methodology for measuring third mission activities of universities. https://www.researchgate.net/publication/293632889 A NEW METHODOLOGY_FOR_MEASURING_THIRD_MISSION_ACTIVITIES_OF_UNIVERSTITIES Ūtolsó letöltés: 2018 . december $\overline{16}$.

Chatterton, P. \& Goddard, J. (2000). The Response of Higher Education Institutions to Regional Needs. European Journal of Education, 35(4), 475-496. DOI: $10.1111 / 1467-3435.00041$

Czakó Erzsébet (2000). Versenyképesség iparágak szintjén-a globalizáció tükrében. PhD disszertáció. Budapest: BKÁE Vállalatgazdaságtan Tanszék.

E3M: European indicators and ranking methodology for university third mission. http://www.prepare-net. com/sites/default/files/european_indicators_and_ranking_methodology_for_university_third_mission_pdf. pdf Uttolsó letöltés: $20 \overline{19}$. 09. 28.

Gál Zoltán (2016). Egyetem és város. Educatio, 25(2) 220-233.

Gibb, A. A. (2013). Developing the Entrepreneurial University of the Future. Key Challenges, Opportunities and Responses. Paris: OECD.

Halász Gábor (2013). A felsőoktatás globális trendjei és szakpolitikai válaszok az OECD országokban és az Európai Unióban. In Hrubos Ildikó, Luda Szilvia és Török Imre (szerk.), Intézményi menedzsment a felsőoktatásban 3. Budapest: Budapesti Corvinus Egyetem. 13-34. http://docplayer.hu/1366722-Intezmenyi-menedzsment-a-felsooktatasban-3-szerkesztette-hrubos-ildiko-luda-szilvia-torok-imre.html Utolsó letöltés: 2019. 09. 28.

Halász Gábor (2018). Új vonások az Európai Unió és az OECD felsőoktatással kapcsolatos stratégiájában. In Kováts Gergely és Temesi József (szerk.), A magyar felsőoktatás egy évtizede 2008-2017. NFKK Kötetek 2. Budapest: Budapesti Covinus Egyetem Nemzetközi Felsőoktatási Kutatások Központja. 25-38. http:// unipub.lib.uni-corvinus.hu/3302/1/MF_2008-2017.pdf Utolsó letöltés: 2019. 09. 28.

HEInnovate. https://heinnovate.eu/en/about Utolsó letöltés: 2019. 09. 28.

Holland, B. A. (2001). Toward a definition and characterization of the engaged university. Metropolitan Universities, 2(3), 20-29.

Horváth Ákos (2011). Kísérlet az európai mapping rendszer hazai alkalmazására. A klaszterelemzés eredményei. In Hrubos Ildikó (szerk.), Mühelytanulmányok. A felsöoktatási intézmények föbb típusai tevékenységük és vállalt missziójuk szerint. Nemzetközi piacorientáció, korszerü intézményi menedzsment. NFKK Füzetek 8. Budapest: BCE KK NFKK, Aula Kiadó Kft. 31-55.

Hrubos Ildikó (2004). Gazdálkodó egyetem, szolgáltató egyetem, vállalkozói egyetem. In Hrubos Ildikó (szerk.), A gazdálkodó egyetem. Budapest: Felsőoktatási Kutatóintézet, Új Mandátum Könyvkiadó. 14-33.

Hrubos Ildikó (2011). Intézményi sokféleség a felsőoktatásban. In Hrubos Ildikó (szerk.), Mühelytanulmányok. A felsőoktatási intézmények föbb típusai tevékenységük és vállalt missziójuk szerint. Nemzetközi piacorientáció, korszerü intézményi menedzsment. NFKK Füzetek 8. Budapest: BCE KK NFKK, Aula Kiadó Kft. 9-30.

Hrubos Ildikó (szerk., 2012). Elefántcsonttoronyból világitótorony. A felsőoktatási intézmények misszióinak átalakulása, bővülése. Budapest: Aula Kiadó Kft.

Hrubos Ildikó (2013). A felsőoktatási intézmények misszióinak átalakulása, bővülése. In Hrubos Ildikó, Luda Szilvia és Török Imre (szerk.), Intézményi menedzsment a felsöoktatásban 3. Budapest: Budapesti Corvinus Egyetem. 34-44. http:// docplayer.hu/1366722-Intezmenyi-menedzsment-afelsooktatasban-3-szerkesztette-hrubos-ildiko-ludaszilvia-torok-imre.html Utolsó letöltés: 2019. 09. 28.

Hrubos Ildikó (2014). Globális trendek, új kihívások a felsőoktatásban. In Mészáros Attila (szerk.), A felsőoktatás tudományos, módszertani és munkaerőpiaci kihívásai a XXI. században. Győr: SZIE. 272-276. 
Hrubos Ildikó (2018). Új megfontolások az egyetem társadalmi szerepvállalásának értelmezéséhez. In Tóth Dorina Anna (szerk.), Az oktatás gazda(g)sága. Tanulmányok Polónyi István tiszteletére. Oktatáskutatók Könyvtára 5. Debrecen: CHERD-H. 49-57.

Jorge, M. L. \& Peña, F. J. A. (2017). Analysing the literature on university social responsibility: A review of selected higher education journals. Higher Education Quarterly, 71(4), 302-319. DOI: 10.1111/ hequ. 12122

Kálmán Anikó (2013). Az Európa 2020 stratégia: az életen át tartó tanulás és a tudásháromszög megvalósítása az egyetemeken. In Benedek András, Tóth Péter, Kozma Tamás és Perjés István (szerk.), Új kutatások a Neveléstudományban. A munka és a nevelés világa a tudományban. Budapest: MTA Pedagógiai Bizottság, ELTE Eötvös Kiadó. 173-191.

Kerekes Sándor (2013). Az egyetemek társadalmi felelősségvállalása, feladatok és lehetőségek. In Hrubos Ildikó, Luda Szilvia és Török Imre (szerk.), Intézményi menedzsment a felsőoktatásban 3. Budapest: Budapesti Corvinus Egyetem. 126-144. http://docplayer. hu/1366722-Intezmenyi-menedzsment-a-felsooktatasban-3-szerkesztette-hrubos-ildiko-luda-szilvia-torok-imre.html Utolsó letöltés: 2019. 09. 28.

Kotosz, B., Lukovics, M., Molnár, G., \& Zuti, B. (2015). How to Measure the Local Economic Impact of Universities? Regional Statistics, 5(2), 3-19. DOI: 10.15196/rs05201

Kotosz Balázs, Lukovics Miklós, Zuti Bence és Molnár Gabriella (2016). Egyetemi funkciók és helyi gazdasági hatások: módszertani problémák és lehetséges megoldások. In Lengyel Imre és Nagy Benedek (szerk.), Térségek versenyképessége, intelligens szakosodása és újraiparositása. Szeged: JATEPress. 185-203.

Leydesdorff, L. (2013). The Triple Helix of UniversityIndustry-Government Relations. In Carayannis, E. G. \& Campbell, D. F. J. (szerk.), Encyclopedia of Creativity, Invention, Innovation and Entrepreneurship. New York, NY: Springer. 1844-1851. https://www. leydesdorff.net/th12/th12.pdf DOI: 10.1007/978-14614-3858-8 Utolsó letöltés: 2019. 09. 28.

Lux, G. (2010). From Industrial Perphery to Culture Capital? Restructuring and Institution Building in Pécs. In Suchacek, J. \& Petersen, J. (Eds). Developments in Minor Cities: Institutions Matter. Ostrava: Technical University Press. 103-119.

Molnár Gabriella (2015). Egyetemek gazdaságfejlesztési hatásainak számszerüsitése: a harmadik misszió mérési lehetöségei. Szakdolgozat, Szegedi Tudományegyetem, Szeged.
Nemes Gusztáv és Varga Ágnes (2015). Társadalmi innováció és társadalmi tanulás a vidékfejlesztésben-sikerek, problémák, dilemmák, 2015. In Veresné Simon Mariann (szerk), „Mérleg és Kihívások" IX. Nemzetközi Tudományos Konferencia, Konferencia kiadvány. https://www.researchgate.net/ publication/283507926_TARSADALMI_INNOVACIO ES TARSADALMI TANULAS $\overline{\mathrm{A}}$ VIDEKFEJLEESZ̄TESBEN - SIK̄EREK PRŌBL̄EMAK DILEMMAK Utolsó letöltés: 2019. 09. 28.

OECD/EU (2017). Supporting Entrepreneurship and Innovation in Higher Education in Hungary. OECD Skills Studies. Paris: OECD Publishing. DOI: 10.1787/9789264273344-en

Pálné Kovács Ilona (2009). Régiók és fejlesztési koalíciók. Politikatudományi Szemle, 18(4), 37-60.

Polónyi István (2010, szerk.). Az akadémiai szféra és az innováció. A hazai felsőoktatás és a gazdasági fejlödés. Budapest: Új Mandátum Könyvkiadó.

Rechnitzer, J. \& Reisinger, A. (2015). University-city-economy: characteristics of the „Györ model”. In Surdej, A. \& Kędzierski M. (szerk.), Economic Challenges for Higher Education in Central and Eastern Europe. Torun: Wydawnictwo Adam Marszalek. 118-141.

Reisinger Adrienn és Dános Zsolt (2015). Egyetemi felelősségvállalás három magyar egyetem esetében. Tér-gazdaság-ember: a Széchenyi István Egyetem Kautz Gyula Gazdaságtudományi Karának tudományos folyóirata, 3(3), 117-133.

Vallaeys, F. (2014). University Social Responsibility: A Mature and Responsible Definition. Higher Education in the World 5. Letöltve innen: https://www. researchgate.net/publication/265501803_University_Social_Responsibility_a_mature_and_responsible definition DOI: $10.131 \overline{140} / \overline{2} \cdot 1.2121 .152 \overline{3}$

Varga Attila (2004). Az egyetemi kutatások regionális gazdasági hatásai a nemzetközi szakirodalom tükrében. Közgazdasági Szemle, 51(3), 259-275.

Varga Krisztina (2017). Társadalmi innováció mérési lehetőségei. In dr. Keresztes Gábor (szerk.), Tavaszi Szél 2017 Tanulmánykötet. Budapest: Doktoranduszok Országos Szövetsége. 504-517. http://www.dosz. hu/dokumentumfile/TSZ_Kotet_II_2017.pdf Utolsó letöltés: 2019. 09. 28.

Vas Zsófia (2012). Tudásalapú gazdaság és társadalom kiteljesedése: A Triple Helix továbbgondolása-a Quadruple és Quintuple Helix. In Rechnitzer János és Rácz Szilárd (szerk.), Dialógus a regionális tudományról. Györ: SZIE. 198-207. 
Absztrakt
Tanulmányomban a doktori kutatási témámhoz legközvetlenebbül kapcsolódó felsőoktatás-kutatási fogalmak és jelenségek összefoglaló bemutatására vállalkozok az általam eddig megismert hazai szakirodalom alapján. Ebben a magyarországi vidéki egyetemek helyi-regionális közösségi elköteleződése jegyében indított harmadik missziós tevékenységeinek céljait, megvalósításuk módját, eredményeit és nehézségeit, valamint az érdekhordozókra kiváltott hatásait kívánom majd megvizsgálni néhány kiválasztott intézmény és cél, különösen a hallgatói létszámnövelés tekintetében. Ezért tanulmányomban ismertetem a harmadik misszió fogalmát, stratégiai fontosságúvá válásának okait és változatos céljait, a müködési keretét nyújtó négyes és ötös spirál modelljeit, valamint a vállalkozói egyetem és az elkötelezett egyetem koncepcióját. A társadalmi beágyazódás fontosságának növekedése kapcsán körbejárom az egyetemi társadalmi felelősségvállalás fogalmát és megvalósításának lehetőségeit a három küldetésen keresztül, ami rávilágít arra, hogy a társadalmi elköteleződés és szerepvállalás a harmadik misszión belül, de felett is értelmezendő. Majd a gyakorlati megvalósulást példákkal is illusztrálom, röviden bemutatva néhány magyarországi egyetem harmadik missziós, illetve egyetemi társadalmi felelősségvállás szellemében a közelmúltban végzett tevékenységét. Végül a harmadik misszió és a társadalmi innováció mérési lehetőségeit ismertetem a hazai szakirodalom eredményei alapján, majd felvetem a téma kutatásának nehézségeit és lehetséges további irányait. Mindez azt mutatja, hogy az egyetemek társadalmi elköteleződése stratégiailag egyre hangsúlyosabb, és egyre bővülő körü tevékenységekben realizálódik célközönségei, a helyi-regionális társadalom, illetve hallgatóik irányába. Szükséges alapjai viszont intézményesülésük, fenntarthatóságuk biztosítása, az érintettekkel való hatékony és folyamatos együttmúködés, valamint az eredmények mérése. Hatásai megnyilvánulhatnak a régió gazdaságfejlődésében, társadalmi kihívásainak kezelésében, a kulturális, sport- és tudományos élet felpezsdülésében, valamint az egyetemek regionális jellegének erősödésében és felsőoktatás-piaci súlyuk növekedésében. 